\title{
Entrepreneurial Learning: The Transmitting and Embedding of Entrepreneurial Behaviours within the Transgenerational Entrepreneurial Family
}

\begin{abstract}
The aim of this paper is to explore how entrepreneurial behaviours are transmitted and embedded across generations within a Transgenerational Entrepreneurial Family (TEF). Although extant family business research has acknowledged the importance of learning in facilitating the transference of values, norms and attitudes, we know little about how learning embeds entrepreneurial behaviours at the family level. In order to address this, we adopted a longitudinal perspective of four TEF cases, drawing on numerous interviews, archival sources and observational instances. An iterative procedure for data analysis, which involved open coding, within-case analyses, second-order coding and cross-case analysis, was undertaken. Our findings illustrate how the implementation of entrepreneurial behaviours within TEFs was a process of negotiation and reification, informed by differences among families in response to critical incidents. Furthermore, we demonstrate how the presence of entrepreneurial behaviour enablers in each TEF has facilitated the perpetuation of entrepreneurial behaviours. Finally, we illuminate the importance of unlearning, the disregarding of prior learning to accommodate new information and behaviours, in the TEF context, where such entities are faced with unlearning paradoxes that subsequently influence their entrepreneurial behaviours.
\end{abstract}

Keywords: Transgenerational Entrepreneurial Family; Entrepreneurial Learning; Entrepreneurial Behaviours; Critical Incidents; Longitudinal Case Study Methodology. 


\section{Introduction}

Entrepreneurial learning is a social phenomenon which occurs in context (Pittaway and Cope 2007) via a 'process of co-participation' whereby learning involves 'reflecting, theorising, experiencing, and action' (Taylor and Thorpe 2004, 204). This learning is often accompanied by unlearning, the process of setting aside 'prior learning in order to accommodate new information and behaviours' (Becker 2005, 661). Although the family is among the most dominant social institutions when it comes to the transference of values, norms and attitudes to its members (Berger and Luckman 1967), little is known about how family members actually learn about the family in business (Cruz, Howorth, and Hamilton 2013; Konopaski, Jack, and Hamilton 2015). This gap in knowledge is of significance to a particular type of family, namely the Transgenerational Entrepreneurial Family (TEF) (DeWitt et al. 2015). It is frequently the case that, with these types of families, the original entrepreneurial essence of the venture has cascaded down numerous generations of the family, and manifests as a form of 'enterpriseness' within the business family (Frank et al. 2010, 124; Frank et al. 2019; Zellweger et al. 2012).

Despite the significance of entrepreneurial learning for TEFs, the process by which their entrepreneurial essence, through the manifestation of entrepreneurial behaviours, has been transmitted and embedded across generations of the family is a blind spot inherent in the field of family entrepreneurship (Nordqvist and Melin 2010; Randerson, Dossena, and Fayolle 2016). In keeping with recent calls for greater consideration of the family's influence on entrepreneurial processes (Randerson et al. 2017; Sarasvathy et al. 2014), this study adopts the TEF as the unit of analysis to uncover how the family operates as a social system of learning within business. In doing so, we extend understanding of the nuances of heterogeneity in family firms (Dibrell and Memili 2019). Accordingly, within this paper we adopt entrepreneurial learning as our theoretical lens in order to address this gap. Such a lens is appropriate, given that learning as a central component of entrepreneurial practice is widely recognised (Cope 2005), and that cross-generational entrepreneurial practice is characteristic of TEFs (Jaskiewicz et al. 2014).

The aim of this paper is to explore how entrepreneurial behaviours are transmitted and embedded across generations within a TEF. The transmission of behaviours within organisations has been the focus of much family business research (Burke and Baldwin 1999; Randerson et al. 2015; Zhong et al. 2012). Specifically, we will investigate entrepreneurial behaviours associated with entrepreneurial learning and unlearning, in addition to critical incidents - which are defined as episodes that represent key successes or failures (Cope 2005). We achieve this aim through our adoption of a longitudinal multiple case study methodology, consisting of archival records, in-depth interviews and observations with four multigenerational TEFs in Northern Europe.

Within this paper, we make the following contributions: First, we address a research gap inherent in the field of transgenerational entrepreneurship (Randerson, Dossena, and Fayolle 2016), namely the process by which entrepreneurial behaviours are transmitted. Thus, our findings illuminate this process by illustrating how certain critical incidents have an enduring effect on the entrepreneurial behaviours embedded and sustained across generations (De Massis and Kotlar 2014). Second, we highlight that the learning processes in TEFs are bidirectional and multi-generational, involving multiple forms of co-participation from family members (Clinton and Gamble 2019; McAdam et al. 2018). This novel insight demonstrates the mutually influential relationship between individual and familial entrepreneurial behaviours (Bettinelli, Fayolle, and Randerson 2014). Third, our findings illustrate that TEFs must engage in unlearning processes to remain entrepreneurial, thus providing insights into the 
role of unlearning in the entrepreneurial learning process, which is currently lacking (Wang and Chugh 2014). This is significant as many entrepreneurial strategies fail due to unsuccessful navigation of paradoxical tensions between exploring new business practices and exploiting long-held assurances.

To develop these arguments, we commence by outlining the rationale for our theoretical framing, followed by a discrete analysis of entrepreneurial learning, critical incidents and unlearning in the context of entrepreneurship. We then draw these concepts together under the domain of transgenerational entrepreneurship, which forms the basis of our empirical illustration of the analysis. In the following section, we discuss our methodology. This is followed by critical evaluation of the empirical evidence from a longitudinal investigation of four cases from the Successful Transgenerational Entrepreneurship Practices (STEP) ${ }^{1}$ project. We then critically reflect on the entrepreneurial behaviours across our cases, considering the implications for theory and practice.

\section{Learning in an Entrepreneurial Context}

Entrepreneurial learning is a social phenomenon (Gibb 1997) which takes place in context (Pittaway and Cope 2007) via a process of 'co-participation' (Taylor and Thorpe 2004). Given the experiential nature of this process, entrepreneurs learn through a process of action and reflection (Cope and Watts 2000; Politis 2005). One of the key mechanisms within this entrepreneurial learning process is the learning that occurs as a result of critical incidents or episodes that are either significant successes or failures (Cope 2005). Indeed, a central feature of how entrepreneurs learn is through 'major setbacks' (Minniti and Bygrave 2001) and discontinuous, contingent, and critical learning events (Cope 2005; Harmeling and Sarasvathy 2013). Empirically, critical incidents have been shown to influence family firms' innovation endeavours, with such entities not only outliving various critical incidents (e.g. succession) but using them as 'a catalyst for further radical innovation' (McAdam, Reid, and Mitchell 2010, 452).

Interestingly, the role of unlearning in the entrepreneurial learning process is relatively unexplored (Wang and Chugh 2014), despite the concept gaining considerable traction across varying managerial disciplines (Leal-Rodríguez et al. 2015). Unlearning activities may help foster entrepreneurial behaviours such as innovation (Rebernik and Širec 2007; Becker 2010), internationalisation (Casillas, Moreno, and Barbero 2010) and strategic renewal (Volberda, Baden-Fuller, and Van Den Bosch 2001). Thus, unlearning is especially apposite for the TEF as they repeatedly engage in entrepreneurship across multiple generations (Jaskiewicz, Combs, and Rau 2015). This provides a learning opportunity whereby family members accumulate experience that is transmitted to future generations (Cucculelli and Bettinelli 2016; Zahra 2012). However, Becker (2005) argues that embedded knowledge is more difficult to unlearn than newly acquired information. This is particularly relevant to the TEF context as 'the feelings and emotions related to change are likely to be deeper and more intense than those in nonfamily businesses' (Dyer 1994, 125).

Thus, TEFs are presented with a paradox, which involves balancing the familiarity of past behaviours with the uncertainty of the future (Chrisman et al. 2015; De Massis, Vittorio, and Frattini 2016). According to Hamilton $(2011,19)$, 'discontinuity and new practice' in TEFs

\footnotetext{
${ }^{1}$ The STEP project was created in 2005 by Babson College in collaboration with six academic affiliates in Europe. It is a global research initiative that aims to uncover how entrepreneurial mind-sets and capabilities are passed across generations, enabling them to create new streams of value. As of 2015, STEP has grown to include 40 institutions with over 175 scholars across five global regions.
} 
'are as important as continuity and enduring practices'. However, many entrepreneurial strategies fail because family members are unable to manage the paradoxical tensions that exist between exploring novel approaches and exploiting embedded practices (Cegarra-Navarro, Sánchez-Vidal, and Leiva 2011).

\section{The Transgenerational Entrepreneurial Family}

Within the family business field, the TEF is considered distinctive from traditional families in business, which are often considered conservative and risk-averse (Miller and Le-BretonMiller 2005). This distinction has resulted in increased attention afforded to the role of family influence in transgenerational entrepreneurship (Chrisman et al. 2015; Zellweger et al. 2012). Indeed, those families that possess strong transgenerational succession intentions and extensively seek external knowledge have the potential to engage in a high level of corporate entrepreneurship (Randolph, Li, and Daspit 2017). Transgenerational entrepreneurship is the 'processes through which a family uses and develops entrepreneurial mind-sets and family influenced capabilities to create new streams of entrepreneurial, financial, and social value across generations' (Habbershon, Nordqvist, and Zellweger 2010, 1). Such mind-sets are the beliefs and attitudes which are the 'oxygen that feeds the fire of entrepreneurship' within the TEF (Rogoff and Heck 2003, 559).

Hence, what makes the phenomenon of entrepreneurial learning especially relevant for the TEF is not only multigenerational involvement, but also the adoption of an entrepreneurial mind-set with a long-term orientation (McCann, Leon-Guerrero, and Haley 2001; Lumpkin, Brigham, and Moss 2010). Within such a context, longitudinal entrepreneurial performance and entrepreneurial learning are more accurately investigated when the TEF is the unit of analysis rather than a particular business entity (Habbershon and Pistrui 2002, 239). Thus, the TEF's long-term horizons facilitate a repository of learning and hub of entrepreneurial activity (Miller and Le Breton-Miller 2005; Zellweger 2007). Accordingly, we respond to calls for positioning the family at the centre of research exploring the entrepreneurship function of family firms (Nordqvist and Melin 2010; Randerson et al. 2017). This adoption of a family-centred perspective will facilitate insights into the entrepreneurial behaviours of the TEF, which is currently lacking in family business research (Zellweger et al. 2013). However, such an approach is essential to uncovering the transmission of these behaviours across time and generations.

\section{Methodology \\ Research Design}

Given the nature of our research aim, a comparative case study methodology is deemed apposite (Yin 2009). Such an approach aligns with the entrepreneurial learning domain, which relies largely on qualitative analyses (Cope 2011). Within this line of inquiry, it has been suggested that the adoption of multiple data collection procedures (e.g., archival and participant observation) may facilitate 'a deeper and more nuanced understanding of how material practices influence the development of collective interpretations' (Stigliari and Ravasi 2016, 445). In family business research, case studies facilitate theoretical expansion, thus enhancing our understanding of family behaviour (Clinton, McAdam, and Gamble 2018; De Massis and Kotlar 2014). In addition, we adopt a longitudinal stance, consisting of primary data collection at multiple points across a six-year period ${ }^{2}$ (2011-2017) and archival sources dating from 1919-

\footnotetext{
2 This data collection period from 2011-2017 was chosen as it marked the aftermath of a worldwide economic downturn and an increase in entrepreneurial activity in this region (OECD, 2017).
} 
2016. All four TEFs share the same geographical location in Northern Europe. Whilst there is no optimal number of cases per multiple case study design, Eisenhardt (1989) recommends between four and ten cases. Accordingly, four cases are deemed appropriate for this exploratory investigation in order to adhere to replication logic and to pursue distinct patterns of theoretical replications (Yin 2016).

\section{Sampling}

Our sampling was purposeful in that we sought and selected richly detailed cases that related to our aim (Palinkas et al. 2015). Our sample of TEFs was chosen from a pool of case studies in adherence with the STEP project case study protocol. We purposely selected TEFs of multiple and varying generations to account for the transgenerational aspect of the study. In acknowledging the role of family heterogeneity in the transgenerational transmission of entrepreneurial behaviours, additional family-specific criteria were applied to our sampling strategy. For each TEF, we sought information on the number of group members and living generations, the geographical dispersion of TEF members and the frequency of meetings among members. In addition, we sought TEFs that had experienced different types of family ownership transitions (Gersick et al. 1997). An overview of each case is provided in Table 1 and case vignettes can be viewed in Appendix 1.

[Table 1 here]

\section{Data Collection}

Archival Records

We gathered hundreds of items of evidence that were either publicly available or provided by the TEFs. These archival records (345 pieces of evidence in total) allowed the research team to trace the four TEFs back almost a century. Archival sources ranged from reports and published corporate histories to newspaper articles and blog posts. Furthermore, we cross compared the records with interviews and observations to confirm findings, reach consensus, and achieve triangulation, thereby enhancing the credibility of our findings (Yin 2016). See Table 2 for a review of all archival sources.

[Table 2 here]

\section{Interviews}

Our semi-structured interviews, averaging 54 minutes in duration, were conducted with 32 participants across the four TEFs over a four-year period (2011-2015). Of the interviews conducted, eight were with family owner/MD/Chairman/Board members, eight were with next generation members, and 16 were with non-family managers, advisors, and other stakeholders. Consistent with Eisenhardt $(1989,536)$ who claims that 'a priori specification of constructs can shape the initial design of theory building research', the STEP guide posed pre-set questions relating to family business and entrepreneurship constructs. The questions most pertinent to our research aim related to the business family history, externalities, and culture that might indicate critical incidents throughout the business family's life (See Appendix 2 for the list of questions). This round of questioning preceded follow-up interviews which served to clarify, refine, and bolster the data. The interviews were transcribed verbatim resulting in 548 pages of transcript from approximately 27 hours of tape.

\section{Observations}

In order to achieve within-method triangulation (Bekhet and Zauszniewski 2012), we used observations as our third data collection method. In total, 27 observational instances, ranging 
from family council meetings to plant tours, were observed over a six-year period (2011-2017). As suggested by Yin (2016), the data collection procedure for observations required the researcher to note the time and location, the participants present and the type of observation. Two research team members acted as participant observers who kept field notes while generating observations. See Table 3 for a comprehensive review of interview and observation data.

[Table 3 here]

\section{Data Analysis}

In keeping with our inductive approach, our data analysis was an iterative process between the data and the emerging theory (Eisenhardt 1989). Analysis was carried out by two members of the research team who were both highly familiarised with the case firms. The initial phase of analysis involved compiling and documenting all textual data including interview transcriptions, field notes, observations, and archival evidence on each of the four TEFs. As a result of this process, a case study database was formed (De Massis and Kotlar 2014). This provided the basis for our structured process for data analysis (Miles and Huberman 1994) comprising of open coding, within-case analyses, second-order coding, and cross-case analysis.

\section{Open Coding}

Two researchers coded the data for critical incidents, resulting in a list with an accumulative total of 34 critical incidents. Given the subjective, retrospective nature of critical incident retelling (Cope and Watts 2000), we sought to enhance the credibility of our findings (Lincoln and Guba 1985) by including only the occurrences deemed critical as corroborated by evidence from at least one major data source (i.e. ' $\mathrm{A}$ ', evidence from 4+ interviewees; or ' $\mathrm{C}$ ', evidence from $4+$ archival types) and one minor data source (i.e. 'a', evidence from $2+$ interviewees; or 'c', evidence from $2+$ archival types).

\section{Within-case Analyses}

Case descriptions were written to enhance our understanding of the family in business and its rich history and allow for within-case patterns to emerge (Eisenhardt 1989). We then uncovered patterns in the data whereby a critical incident was followed by a learning outcome (Yin 2009). This was conducted by two members of the research team who acted as independent raters, with both raters meeting periodically to discuss their analysis and resolve any discrepancies. A third member of the research team acted as an independent referee (Sieger et al. 2011). These learning outcomes formed our first-order codes.

\section{Second-order Coding}

In the next phase of analysis, we searched for second-order codes that could group these learning outcomes into themes. Thus, five distinct entrepreneurial behaviours (e.g., opportunity seeking/recognising; risk-taking; striving for efficiency; strategic regenerating; and diversifying products and/or markets) were identified. Our five identified behaviours were subsequently corroborated with evidence from secondary sources (e.g., financial accounts filed with the National Companies Register). Consistent with the theory building process, this stage of analysis was an iterative cycle between the data, emerging theory, and existing literature (Eisenhardt and Graebner 2007).

\section{Cross-case Analysis}

In the final phase of coding, we searched for themes that could explain how these entrepreneurial behaviours were transmitted and embedded across generations as a result of the 
critical incidents and learning outcomes. A cross-case comparison technique was conducted whereby certain categories were used to determine patterns of similarity and difference across the cases (Eisenhardt 1989). This led to the identification of five aggregate dimensions or entrepreneurial behaviour enablers. These enablers (e.g., predecessor legacy building; safeguard family control and influence; reduced ownership complexity) facilitated the transmission and embedment of entrepreneurial behaviours across generations. The use of enablers to enhance entrepreneurial vitality has been advocated by other management scholars (see Kuratko, Montagno, and Hornsby 1990; Yamada 2004), who acknowledge that they can exert a range of heterogeneous effects on entrepreneurial capabilities and behaviours (Mwasalwiba, Dahles, and Wakkee 2012). All five entrepreneurial behaviour enablers can be viewed in Appendix 3 and the data analysis procedure followed for each TEF can be viewed in Tables 4-7.

\section{Findings}

We now present findings, in which our identified entrepreneurial behaviours are explored in detail and illustrated with fragments of the narrative or 'power quotes' (Pratt 2008, 501).

\section{Critical Incidents}

According to one of the Co-MDs (G3) in TEF A, a major critical incident for the family was the home plant fire that occurred in 2004 (see Table 4). The G3 Co-MD recounted the night of the fire, with 'people coming up and looking for a sense of direction. I have inherited the responsibility of their families'. Subsequently, the brothers needed to make a strategic decision regarding the future of the home plant and those it employed: 'What matters [is] giving a sense of localness, being part of the community' (BD G3). Our interview data collected during the initial research period revealed that the decision to forgo the home plant and focus efforts on the secondary plant and other opportunities for growth (e.g., international acquisitions) was considered by the G3 Co-MDs to be 'a difficult one but it was the right decision'. This opportunity seeking behaviour subsequently resulted in success and acclaim when the brothers later won the Ernst \& Young Industry Entrepreneur of the Year Award (Press release 2010). The Co-MDs also drew from past experiences: their father and first-generation MD sought and acquired supply from a neighbouring country. Indeed, the interview data collected during the initial research period, corroborated by more recent archival sources, indicate that the Co-MDs later unified and aligned the objectives of their father's legacy by acquiring firms in this particular country: 'Dad always said, "it is ok to make mistakes, you need to try" (Co-MD G3).

[Table 4 here]

Our second-round interviews revealed that, in TEF B, the current Managing Director's (G6) attempted diversification into 'ready to eat' cereals was a critical incident that led to failure (see Table 5). This failure offset both learning and unlearning as the family discarded their previous assumptions about diversifying: 'We failed, learned from it and moved on' (MD G6). Notably, the family only diversified within the core product offering. These findings echo a similar measured risk-taking strategy by TEF A as a response to a critical incident of $£ 30$ million worth of trees felled by a hurricane, after which the second-generation MD 'bought enough timber to supply the mill in [the home plant] for two years' (excerpt from the TEF A's Biographical Book). 
According to a Board Member (G1) in TEF C, a prominent critical incident was the decision to withdraw from the electrical goods market and focus on pumps as the core product offering (see Table 6). As the G1 Co-Founder explained, 'We took the decision to get out of all brown goods, white goods, and all that'. Interview data collected during the initial research period revealed that this incident allowed the TEF to 'change the whole market [both nationally and abroad] and bring in new products' (DMD G2). The TEF embraced these learnings and even became flexible in their personal lives: 'We got the agency on the condition that we open two branches: one in the Midlands and one in the West. I was dispatched to the West' (MD G1).

\section{[Table 6 here]}

For TEF D, a key critical incident was when the Executive Chairman (G1) returned from a period of illness in 2012 and began restructuring the company (see Table 7). He explained: 'I looked at a lot of companies, but [Firm D] fitted very simple criteria'. A non-family Legal Advisor provided a further insight into the Executive Chairman's restructuring goals for the firm: 'He is hoping to have a sustainable capable business where -- either directly or indirectly, the family would get a return from their efforts.' It appears that his attainment of this goal involved a long experiential learning process of trial and error: 'The Executive Chairman has this concept about a shared or collective governance structure' (Auditor non-family). The other critical incident for TEF D was the establishment of the family holdings group, which was strategically created to instil entrepreneurial learning through the insourcing of advice from 'two separate entities outside of TEF D' (GM G2).

[Table 7 here]

\section{Bi-directionality and Co-participation}

Our findings reveal insights into co-participation and bi-directionality in family entrepreneurial behaviours in TEF C (see Table 6), notably when the second-generation Deputy Managing Director was mentored by a non-family, shareholding director. This embedded opportunityseeking behaviour resulted in the formulation of an intra-firm consortia and first-to-market contracts. A learning that emerged from this incident is the significance of thinking long-term regarding 'big growth and opening up more opportunities' (DMD G2) - an entrepreneurial behaviour that has been transmitted across the two generations of the family. Whereas in TEF A, the second-generation Co-MDs embarked on their first acquisition, the family's most prominent example of risk-taking (see Table 4), with the continued backing and advice of their father 'who understood deeply that this was the defining event in the transition to the next generation'. Furthermore, according to archival sources, they were 'increasingly becoming key decision makers in the business' (Excerpt from the TEF's Biographical Book).

In TEF D, as a serial entrepreneur, the Executive Chairman demonstrated an 'enterpriseness' (Frank et al. 2010, 124) that was characterised by heightened risk-taking and 'maximisation of available assets' (EC G1). These entrepreneurial behaviours were evident in the secondgeneration members of TEF D who, via the family holdings group, personally developed, embraced risk-taking, and created their own space in the market: 'There is definitely going to be diversification but not necessarily within [TEF D]' (GM G2). A prominent example of diversification also occurred in 2014 with the establishment of their online marketplace that 'helps farmers and contractors secure the best prices' (Website 2017). 
For TEF B, their infusion of bi-directionality and co-participation in entrepreneurial behaviours is grounded in their acknowledgement of differing opinions and approaches (see Table 5).

\section{The Unlearning Paradox}

As evidenced in two stages of interviews and in-depth observations (board meeting, family council meeting) during the closing research period, the sixth generation MD of TEF B implemented a policy whereby all next generation members had to obtain prior external experience: 'Once you see good practice in operation, that's what you aspire to' (BDO G7). Thus, the next generation acquired entrepreneurial education and experience that has not only offset learning but also unlearning through the disregarding of previous operational approaches (see Table 5). In turn, the next generation members have imparted learnings to the incumbent generation regarding best practices obtained from international work experience (e.g., computerisation), as well as unlearning in relation to outdated practices. In addition to their policy of new generations gaining external experience to inform their learning (and unlearning), the TEF has bolstered this with a research driven approach to new product development i.e. focus groups. These two motivations for learning/unlearning insights have subsequently embedded efficiency behaviours, in addition to value enrichment for the TEF due to the evidence of predecessor legacy building: 'Dad would not want to let it get out of the family. It is part of the family history' (FC G7). In contrast with TEF C, there was no such employment conditions for next generation, as indicated by the second-generation Deputy Managing Director who obtained a basic third level college degree before entering the business (see Table 6).

As evidenced by archival and early-stage interview data, paradoxical tensions emerged in TEF A following the home plant fire (see Table 4). The brothers were devastated by the incident with 'the only solace being that [their father] was not alive to see the destruction' (Excerpt from the TEF's Biographical Book). Nevertheless, the brothers effectively changed their approach by unlearning their engrained belief that they must preserve the home plant: 'It really broke my heart to say it, but we said [rebuilding is] not the right solution' (Co-MD G3).

The unlearning paradox was also evident in TEF B on the entry of the seventh generation to the firm: 'None [of the next generation] should go back in directly. So, [my children] have both got experience in other fields in other countries' (MD G6). Following this work experience, the next generation attempted to diversify by introducing new product flavours (see Table 5). However, closing interviews revealed that certain organisational members preferred a more calculated approach to these introductions, so that new product development processes could be effectively implemented: 'You will need a lot of lead time before any new products are brought out' (FC G7). In TEF C, early to midway interviews revealed that the family chose to unlearn their policy on exclusive family ownership when a key non-family member requested shares (see Table 6), as the recruitment of this Technical Director played a 'major role' in growing the company (News article 2012).

In TEF D, unlearning by the individual family members played a major part in company restructuring (see Table 7). Contemporary archival data and early-stage interviews with second generation management reveal that when the Executive Chairman returned to the company, the TEF experienced an unlearning paradox: 'My dad got sick for a while, he was outside of the business. So, I just had to fill that gap' (BDO G2). They could either retain their current 'tried and tested' business practices or unlearn and embrace a new emphasis on consolidating the product range and maximising efficiency. As evidenced by archival data, striving for efficiency 
is a behaviour embedded in the next generation; in 2007, the New Business Development Manager (G2) implemented a new ERP system and fostered greater technology usage to minimise costs. 'It's very advanced and the machine runs incredibly smoothly.... It's going to be way ahead of the competition' (GM G2).

\section{Discussion and Propositions}

In alignment with other research into entrepreneurial families (De Massis and Kotler 2014; Lechner and Dowling 2003), we now present the discussion of our empirical findings along with theoretical propositions for entrepreneurial learning in TEFs.

\section{The Relevance of Critical Incidents for Entrepreneurial Learning in TEFs}

This study demonstrates how entrepreneurial learning triggered by critical incidents is a key mechanism in understanding how entrepreneurial behaviours are transmitted and embedded across generations within a TEF. From our empirical findings, we have observed how TEFs, in the event of disaster-based critical incidents, learn to use their sense of 'family protectiveness' with all employees, and how this responsibility to provide direction informs their subsequent regeneration. We now also understand that in specific circumstances, it is necessary for TEFs to change their approach by disregarding one entrepreneurial behaviour (such as strategic regeneration after a critical incident) as an antecedent for the embedment of another (such as opportunity seeking for growth and acquisition), because they collectively believe that it is the right decision for them as a family. Azadegan and Dooley $(2010,3)$ argue that entrepreneurial learning is informed by incidents of the past and incidents yet to emerge as entrepreneurial families 'teeter on the exploratory or totter on the exploitative sides of a learning see-saw'. If no precedent is set for a critical incident, then the learning that arises is largely explorative and based on the probability that such actions will save them. Our findings reveal that being opportunity-seeking, resourceful and risk-taking are entrepreneurial behaviours that can be transferred from first to subsequent generations of a TEF through predecessor legacy building. This longitudinal learning progression is reminiscent of the theoretical underpinnings of exploitative learning, as defined by Li et al. $(2014,275)$ as deriving from 'the knowledge and skills that are familiar with the firms' current experiences.' Our findings advance this theoretical position by demonstrating that the exploitation of not only current but also preceding experience in TEFs has led to three distinct learning outcomes: first, the prioritisation of business over non-financial interests (including family-related); second, sustaining the workforce; and third, seeking new means of growth.

Proposition 1: Within TEF contexts, as a result of the behaviour enabler of family legacy unification and emulation, longitudinal and exploitative learning may be integral to the embedment of entrepreneurial behaviours, in particular, strategic regeneration and opportunity recognition.

Minniti and Bygrave (2001) argue that entrepreneurial learning can emerge from an action learning process, in which the entrepreneur repeats choices that have been fruitful and disregards options that have amounted to failure. This action learning process, according to Waddill and Marquardt (2011), is grounded in theoretical perspectives of adult learning, in which reflective inquiry favours a cognitivist approach. Our findings advance this theoretical approach to entrepreneurial learning by revealing two salient learning outcomes for TEFs: first, they should persevere with the core product offering in which the family specialises; and second, they should take more measured risks in the future by conducting market research. The comparison of our historical and contemporary archival findings demonstrates that, despite a conservative approach, innovation is still a major part of the TEF's approach. 
Proposition 2: From the perspective of TEFs, the behaviour enablers of entrepreneurial mentoring can forge strong relationships between failure-driven learning outcomes and the subsequent transmission of entrepreneurial behaviours, namely diversification and risk-taking, even when implemented in a calculative and measured way.

Cope (2005) postulates that entrepreneurial learning processes involving radical change can facilitate 'higher-level' learning outcomes, which in turn create the capacity for differentiated actions. In adherence with Kolb's (1984) theory of experiential learning, this process of entrepreneurial learning entails experience, reflection, cogitation and action. Our findings expand upon these theoretical concepts by showing how three distinct higher-level learning outcomes can emerge from radical changes in TEF entrepreneurial behaviour, when combined with subsequent experiential learning to achieve desired goals: first, develop a strong product offering; second, grow the business through geographical expansion; and third, become adaptive to difficult market conditions. As indicated by our empirical data, learning outcomes can remain relevant if senior family members handle recessionary challenges by continuing to grow through innovation, risk-taking and internationalisation.

Proposition 3: In TEFs, the family's involvement impacts not only the behaviour exhibited by the TEF but also the rationale behind family and firm decision making.

Furthermore, the TEF's resultant 'enterpriseness' (Frank et al. 2010, 124) may then manifest in another entrepreneurial behaviour - namely diversification - which is a cornerstone of firm strategy (Garg and Eisenhardt 2017).

\section{Bi-directionality and Co-participation in TEF Entrepreneurial Behaviours}

In line with entrepreneurial learning theory, Cope (2005) conceptualises social characteristics as a dynamic and integrative approach to entrepreneurial learning. Building on this construct, García-Álvarez, López-Sintas, and Saldaña Gonzalvo (2002, 196) consider entrepreneurial mentoring to be a form of these social characteristics, which is 'reserved only for founders' potential successors and begins when successors work full time in the business'. This occurs when the incumbent generation provides autonomy and support to the next generation in pursuing entrepreneurial endeavours. Non-family managers often assume a mentoring position with next generation members (Poza 2010). Hamilton $(2011,17)$ states that 'the next generation have the knowledge of how to run the business having developed a skilled identity'. Our findings show that the learning processes in a TEF are not only bi-directional and multigenerational (Clinton and Gamble 2019), but also socially constructed as they involve multiple forms of 'co-participation of entrepreneurial learning' (Taylor and Thorpe 2004, 204) from external members of the family.

Proposition 4: Due to behaviour enablers of entrepreneurial education and experience, TEFs should adopt a more receptive and combinative approach to family-based and externally-based knowledge acquisition as a means to facilitate multi-generational long-term opportunities and diversification.

Getz and Carlsen $(2005,242)$ describe a successful family in business as one which may 'allow children a degree of autonomy and to take risks'. Hence, it is evident from our findings that subsequent generations of a TEF not only learn from participation but apply their own venturing knowledge to the group, thus making the learning process and behaviour transmission bi-directional. The salient learning outcomes of this critical incident are as follows: first, allow the next generation space to build an entrepreneurial portfolio; and second, 
grow the business via diversification. As uncovered here, this type of entrepreneurship is of particular pertinence to TEFs, as it can provide multiple opportunities and income sources for a large next-generation family management cohort (Carter and Ram 2003; Sieger et al. 2011).

Proposition 5: Diversification behaviours in TEFs are enabled by predecessor legacy building and are a result of the bi-directionality of internal/external knowledge transmission combined with learning outcomes.

\section{The Unlearning Paradox in Transgenerational Entrepreneurial Families}

Another distinctive feature of our TEFs is multi-generational family involvement, which brings diverse opinion and input, in turn fostering entrepreneurial ideation (Kellermans et al. 2008). García-Álvarez, López-Sintas, and Saldaña Gonzalvo $(2002,194)$ argue that formal education and training are components of a family socialisation process experienced by the next generation. They suggest that this formal period of education and training is coupled with entrepreneurial learning and training, which together facilitate 'strong emotional aspects and cognitive learning that are the basis for a descendant's identification with his or her own family'. In our study, the data reveal that the next generation managers of a TEF attain a higher level of education and more external work experience than their predecessors. Resultantly, this affords them 'a greater ability to engage in analysing markets and competitors in order to find room for new entrepreneurial activities' (Cruz and Nordqvist 2012, 37), thus facilitating the incoming transfer of learned entrepreneurial behaviours (i.e. opportunity recognition and diversification). This approach is consistent with Costello's (1996) interpretation of entrepreneurial learning theory through a combination of constant and habitual learning, in which pre-established knowledge is applied to new problems. In our study, the next generation family members of a TEF can impart past learnings to the incumbent generation regarding best practices obtained from work experience, as well as unlearnings in relation to outdated practices to mitigate against future issues. This can subsequently embed efficiency behaviours, in addition to value enrichment for the TEF due to the evidence of predecessor legacy building from the family.

Proposition 6: The opportunities facilitated by external learning via qualifications, as well as unlearning via legacy building behaviour enablers, lead to the transfer and embedding of entrepreneurial behaviours in TEFs that are more inward-facing (i.e. striving for internal operation efficiency and value enhancement) as opposed to outward-facing (i.e. diversifying with new products or markets).

These insights advance entrepreneurial learning theory by extending findings from GarciáÁlvarez, López-Sintas, and Saldaña Gonzalvo (2002), who suggest that founders who view the firm as a means for the family are likely to have a next generation with a lower level of formal education and whom at a young age join the firm at an entry-level position.

While it is necessary for TEFs to transmit and embed entrepreneurial behaviours across family generations, Becker $(2010,265)$ proposes that unlearning is the overlooked aspect of 'ensuring that individuals relinquish, or at the very least refine, existing knowledge and behavior' that can result in more efficient learning and change processes. It is essential that TEFs unlearn and uncover new business practices; however, Chirico and Nordqvist $(2010,6)$ assert that the culture of some families makes them 'inflexible, resistant to change and inclined to stick to path-dependent traditions'. This, according to Ingram et al. (2016), creates paradoxical tensions that pervade TEFs and in some cases can cause the diminishment of innovative firm behaviours. Sole and Wilson $(2002,4)$ have stated that unlearning is fundamentally challenging 
because 'we need to unlearn practices and mental frames that we don't even realise we rely on'. Our findings advance this statement by demonstrating how the families' decisions to unlearn a mind-set on which their entire viewpoint is shaped is not only arduous but essential if entrepreneurial behaviours (e.g. risk-taking and strategic renewal) are to be embedded. These insights lend weight to the theoretical suggestion by Wang and Chugh (2014) that entrepreneurial families are prone to a higher level of exploratory unlearning, compared to their non-entrepreneurial counterparts.

Proposition 7: Due to the behaviour enablers of family legacy unification and emulation, TEFs are not invariably inflexible to changing path-dependent family traditions, as they have shown to exhibit strategic use of unlearning and alternative regeneration approaches as part of their crisis management process.

Resistance to change is reflective of older organisations where repeat practices become embedded and thus their perpetuation is legitimised (Tsang and Zahra 2008). Schuman, Stutz, and Ward (2010) theorise that business families can manage the unlearning paradox by not substituting one demand for another. Resulting from our empirical findings, we now also know that the TEF can unlearn the mind-set about keeping the core product unaltered, whilst retaining the quality and authenticity of their product.

Unlearning is not an end in itself; rather it leads to the embedding of new knowledge and behaviours (Becker 2010) and as evident in this case, an increased appetite for opportunity exploration. Klein (1989) argues that the original learning is still available, and the individual chooses the knowledge and behaviour that fits the current context. Our findings build on this logic by demonstrating that this mind-set can re-emerge when shareholding stakes are returned to the TEF.

Proposition 8: Where a TEF chooses to unlearn their policies on exclusive family ownership, the paradoxical tension between unlearning and retaining the mind-set of safeguarding family control and influence emerges.

As evidenced by our study, striving for efficiency is a behaviour embedded in later generations of a TEF. Akgün et al. $(2007,800)$ state that unlearning differs from the broader concept of organisational change, in that it serves as 'a stage or catalyst [...] in the change process to make it a dynamic process'. Our longitudinal findings thereby indicate that, for TEFs, the change is not instigated by the unlearning process itself, but by the implementation of the entrepreneurial behaviours as a corollary of family and non-family members forgoing their taken-for-granted assumptions of business management.

Resulting from the above discussion and propositions, we now present our theoretical model (see Figure 1 below), in which our eight propositions are visually depicted in terms of their relationship to each other and to the constructs of our research paradigm.

\section{Conclusion}

[Figure 1 here]

Within this paper, we make the following theoretical contributions. Our first contribution is to the entrepreneurial learning domain, where we advance knowledge of how collective learning occurs among entrepreneurial families (Wang and Chugh 2014) by demonstrating how entrepreneurial learning, triggered by critical incidents, is a key mechanism in understanding how entrepreneurial behaviours are transmitted and embedded across generations within a 
TEF. As showcased by our findings and discussion, all generations in the TEF have the potential to transmit entrepreneurial behaviours via learning as stimulated by critical incidents (Cope and Watts 2000). This is especially relevant during critical incidents relating to entry of the next generation to the firm, when new members may possess valuable venturing knowledge and experience. We suggest that TEFs should adhere to a more open and multi-faceted approach to external and internal knowledge acquisition as a catalyst for multi-generational long-term diversification and opportunistic behaviour.

Our second contribution is to the family entrepreneurship literature by extending a theoretical model and propositions for the transmission and embedment of entrepreneurial behaviours in TEFs (Randerson, Dossena, and Fayolle 2016). Accordingly, by addressing calls to prioritise the family in the study of family firm entrepreneurship (Nordqvist and Melin 2010; Randerson et al., 2017), we highlight that the transfer of entrepreneurial behaviours in a TEF is represented by a bi-directional, co-participative and multi-generational learning process (McAdam et al. 2018). Specifically, we demonstrate that subsequent generations of a TEF not only learn from participation but apply their own venturing knowledge to the group via portfolio entrepreneurship, thus demonstrating the bi-directional transmission of risk-taking and diversification. This novel insight discounts the assumption within the literature that the transmission of entrepreneurial behaviours between generations is one directional (Randerson et al. 2015), while also empirically highlighting the bi-directional relationship between individual and family entrepreneurial behaviours (Bettinelli, Fayolle, and Randerson 2014).

Our third contribution relates to unlearning and its role in the entrepreneurial learning process, which requires greater attention (Wang and Chugh 2014). Interestingly, our study shows that for TEFs to be entrepreneurial, members must engage with an unlearning paradox: a dual process of retaining practices that work and unlearning practices that are non-economical, obsolete, or misleading. Hence, we conclude that unlearning via legacy building in TEFs may result in the embedment of more inward-facing entrepreneurial behaviours such as value enhancement and internal operation efficiency as opposed to external behaviours such as diversification (Garciá-Álvarez, López-Sintas, and Saldaña Gonzalvo 2002). We have also demonstrated that TEFs are more flexible than previously thought in terms of their strategic use of unlearning and unorthodox regeneration approaches, which can have positive implications for their crisis management processes and enabling the transfer of entrepreneurial behaviours. Moreover, we conclude that it is not the unlearning process itself that directly enables change processes in TEFs, but rather the embedding of the entrepreneurial behaviours that arise when both family and non-family executives relinquish their taken-for-granted assumptions surrounding business (Becker 2010).

\section{Managerial Implications}

Given the importance of developing applicative knowledge from family business research (Frank and Landström 2016), we extend some practical implications based on this study. First, in order for TEFs to evolve into an agile learning organisation, they must effectively manage and navigate the unlearning paradox, using a 'both-and' rather than an 'either-or' approach (Schuman, Stutz, and Ward 2010). However, it may be particularly difficult for older TEFs to engage in unlearning due to established practices (Tsang and Zahra 2008). In this case, nonfamily professional advisors and managers may be better positioned to identify and lead organisational change initiatives.

Second, as demonstrated by our study, certain enablers can pre-suppose the transmission of entrepreneurial behaviours between TEF members. While we do not claim that the enablers 
relevant to this study will apply to every transgenerational entrepreneurial family, we note their importance to the transmission of entrepreneurial behaviours between generations. In particular, our findings suggest that TEFs should consider a less complex ownership structure which may secure family influence and foster diversification and business growth.

Finally, in acknowledging that entrepreneurial behaviours vary and 'respond to different mechanisms' (Bettinelli et al. 2017, 522), we show that longitudinal and exploitative learning may be central to the embedment of entrepreneurial behaviours, in particular, strategic regeneration and opportunity recognition. Moreover, in keeping with the action learning process (Minniti and Bygrave 2001), we highlight the connection between failure-driven learning outcomes and the subsequent transmission of entrepreneurial behaviours, namely diversification and risk-taking. Finally, we show how TEF members engage with higher-level learning outcomes and experiential learning to achieve goals, thus showing that the family's involvement impacts not only the behaviour exhibited by the TEF but also the rationale behind family and firm decision making.

\section{Limitations and Future Research}

In addressing the limitations of this research, we also suggest avenues for future work. For instance, our study concentrated on a single geographical context (a region of Northern Europe). Although this has enabled us to control for cultural variation (Salvato \& Corbetta, 2013), future research could explore the entrepreneurial learning process within TEFs across various cultural contexts. Our understanding of the cyclical relationship between learning and unlearning could be greatly enriched by the adoption of an institutional perspective. Another limitation of our study is that our results are affected by survivor bias. We acknowledge that our results are biased by our selection of TEFs that have proven successful in the phenomena under investigation (Zellweger et al. 2012). Future research could track the entrepreneurial learning of TEFs over a longer period, including firms that were sold or dissolved.

This study has also contributed to theory-building as no definitive theory exists for the transmission and embedment of entrepreneurial behaviours within TEFs (Randerson, Dossena, and Fayolle 2016). Our theoretical model and propositions could be used as a foundation from which to test quantitatively a number of hypotheses relating to the relationship between critical incidents and the entrepreneurial process; the influence of TEF heterogeneity on the transmission of entrepreneurial behaviours; and the unlearning paradox in TEFs.

It was our aim in this paper to contribute theoretical knowledge of how entrepreneurial behaviours are transmitted across generations of TEFs via entrepreneurial learning, offset by critical incidents. In doing so, we believe this study provides a significant contribution both to family entrepreneurship and entrepreneurial learning domains, in addition to the emerging field of transgenerational entrepreneurship. 


\section{References}

Akgün, A.E., J.C. Byrne, G.S. Lynn, and H. Keskin. 2007. "Organizational unlearning as changes in beliefs and routines in organizations." Journal of Organizational Change Management 20(6): 794-812.

Azadegan A, and K.J. Dooley. 2010. "Supplier innovativeness, organizational learning styles and manufacturer performance: An empirical assessment." Journal of Operations Management 28(6): 488-505.

Becker, K.L. 2005. "Individual and organisational unlearning: directions for future research." International Journal of Organisational Behaviour 9(7): 659-670.

Becker, K. 2010. "Facilitating unlearning during implementation of new technology." Journal of Organizational Change Management 23(3): 251-268.

Bekhet A.K., and J.A. Zauszniewski. 2012. "Methodological triangulation: An approach to understanding data." Nurse Researcher 20(2): 40-43.

Berger P., and T. Luckmann. 1966. The Social Construction of Reality: A Treatise in the Sociology of Knowledge. London: Penguin.

Bettinelli, C., A. Fayolle, and K. Randerson. 2014. "Family entrepreneurship: A developing field." Foundations and Trends® in Entrepreneurship 10(3): 161-236.

Bettinelli C., S. Sciascia, K. Randerson, and A. Fayolle 2017. "Researching entrepreneurship in family firms." Journal of Small Business Management 55(4): 506-529.

Burke L.A., and T.T. Baldwin. 1999. "Workforce training transfer: A study of the effect of relapse prevention training and transfer climate." Human Resource Management 38(3): 227-241.

Carter S., and M. Ram. 2003. "Reassessing portfolio entrepreneurship." Small Business Economics 21(4): 371-380.

Casillas J.C., A.M. Moreno and J.L. Barbero. 2010. "A configurational approach of the relationship between entrepreneurial orientation and growth of family firms." Family Business Review 23(1): 27-44.

Cegarra-Navarro J.G., M.E. Sánchez-Vidal, and D. Leiva. 2011. "Balancing exploration and exploitation of knowledge through an unlearning context: An empirical investigation in SMEs." Management Decision 49(7): 1099-1119.

Chirico F., and M. Nordqvist. 2010. "Dynamic capabilities and trans-generational value creation in family firms: The role of organizational culture." International Small Business Journal 28(5): 487-504.

Chrisman J.J., J.H. Chua., A. De Massis, F. Frattini and M. Wright. 2015. "The ability and willingness paradox in family firm innovation." Journal of Product Innovation Management 32(3): 310-318.

Clinton, E. and J.R. Gamble. 2019. "Entrepreneurial behavior as learning processes in a transgenerational entrepreneurial family." In Entrepreneurial Behaviour: Individual, Contextual and Microfoundational Perspectives, edited by: McAdam, Maura, and James A. Cunningham, 237-260. Palgrave MacMillan.

Clinton, E., M. McAdam, and J.R. Gamble. 2018. "Transgenerational entrepreneurial family businesses: An examination of the business model construct." Journal of Business Research 90: 269-285.

Cope, J. 2005. "Toward a dynamic learning perspective of entrepreneurship." Entrepreneurship Theory \& Practice 29(4): 373-397.

Cope, J. 2011. "Entrepreneurial learning from failure: An interpretative phenomenological analysis." Journal of Business Venturing 26(6): 604-623. 
Cope, J. and G. Watts. 2000. "Learning by doing-an exploration of experience, critical incidents and reflection in entrepreneurial learning." International Journal of Entrepreneurial Behavior \& Research 6(3): 104-124.

Costello, N. 1996. "Learning and routines in high-tech SMEs: Analyzing rich case study material." Journal of Economic Issues 30(2): 591-597.

Cruz, A.D, C. Howorth, and E. Hamilton. 2013. "Intrafamily entrepreneurship: The formation and membership of family entrepreneurial teams." Entrepreneurship Theory \& Practice 37(1): 17-46.

Cruz, C., and M. Nordqvist. 2012. "Entrepreneurial orientation in family firms: A generational perspective." Small Business Economics 38(1): 33-49.

Cucculelli, M., and C. Bettinelli 2016. "Corporate governance in family firms, learning and reaction to recession: Evidence from Italy." Futures 75: 92-103.

De Massis, A., and J. Kotlar. 2014. "The case study method in family business research: Guidelines for qualitative scholarship." Journal of Family Business Strategy 5(1): 1529.

De Massis, D., A. Vittorio, and F. Frattini. 2016. "Mastering innovation in family firms: how to resolve the ability vs. willingness paradox." The European Business Review.

DeWitt, R., N. Auletta, M.J. Parada, M. Yusof, and P. Sharma. 2015. "Developing next generation leaders." In Developing Next Generation Leaders for Transgenerational Entrepreneurial Family Enterprises, edited by Pramodita, Sharma, Nunzia Auletta, Rocki-Lee DeWitt, Maria José Parada, and Mohar Yusof, 1-20. Northampton: Edward Elgar Publishing Ltd.

Dibrell, C. and E. Memili. 2019. "A brief history and a look to the future of family business heterogeneity: an introduction." In The Palgrave Handbook of Heterogeneity among Family Firms, edited by Memili, E., and C. Dibrell, 1-15. Cham: Palgrave Macmillan.

Dyer, W. G. 1994. "Potential contributions of organizational behavior to the study of familyowned businesses." Family Business Review 7(2), 109-131.

Eisenhardt, K.M. 1989. "Building theories from case study research." Academy of Management Review 14(4): 532-550.

Eisenhardt, K.M. and M.E. Graebner. 2007. "Theory building from cases: Opportunities and challenges." Academy of Management Journal 50(1), 25-32.

Frank H., and H. Landström. 2016. "What makes entrepreneurship research interesting? Reflections on strategies to overcome the rigour-relevance gap." Entrepreneurship \& Regional Development 28(1-2): 51-75.

Frank, H., M. Lueger, L. Nosé, and D. Suchy (2010). "The concept of "Familiness": Literature review and systems theory-based reflections." Journal of Family Business Strategy 1(3): 119-130.

Frank, H., J. Suess-Reyes, E. Fuetsch, and A. Kessler (2019). "Introducing the enterpriseness of business families: A research agenda." In The Palgrave handbook of heterogeneity among family firms, edited by Memili, E., and C. Dibrell, 263-296. Cham: Palgrave Macmillan.

García-Álvarez, E., J. López-Sintas and P. Saldaña Gonzalvo (2002). “Socialization patterns of successors in first-to second-generation family businesses." Family Business Review 15(3): 189-203.

Garg, S., and K.M. Eisenhardt. 2017. "Unpacking the CEO-board relationship: How strategy makinghappens in entrepreneurial firms." Academy of Management Journal 60(5): 1828-1858.

Gersick, K.F., M.M. Hampton, I. Lansberg, and J.A. Davis. 1997. Generation to generation: Life cycles of the family business. Harvard, MA: Harvard Business Press. 
Getz, D., and J. Carlsen. 2005. "Family business in tourism: state of the art." Annals of Tourism Research 32(1): 237-258.

Gibb, A.A. 1997. "Small firms' training and competitiveness. Building upon the small business as a learning organisation." International Small Business Journal 15(3): 13-29.

Goldstein, I.L. 1986. Training in organizations: Needs assessment, development, and evaluation. 2nd ed. Monterey, CA: Brooks/Cole.

Habbershon, T.G., and J. Pistrui. 2002. "Enterprising families domain: Family-influenced ownership groups in pursuit of transgenerational wealth." Family Business Review 15(3): 223-237.

Habbershon, T.G., M. Nordqvist, and T. Zellweger. 2010. "Transgenerational entrepreneurship." In Transgenerational entrepreneurship: Exploring growth and performance in family firms across generations, edited by Nordqvist $\mathrm{M}$, and T. Zellweger, 1-38. Cheltenham: Edward Elgar.

Hamilton, E. 2011. "Entrepreneurial learning in family business: A situated learning perspective." Journal of Small Business and Enterprise Development 18(1): 8-26.

Harmeling, S.S., and S.D. Sarasvathy. 2013. "When contingency is a resource: Educating entrepreneurs in the Balkans, the Bronx, and beyond." Entrepreneurship Theory \& Practice 37(4): 713-744.

Ingram, A.E., M.W. Lewis, S. Barton and W.B. Gartner. 2016. "Paradoxes and innovation in family firms: The role of paradoxical thinking." Entrepreneurship Theory \& Practice 40(1): 161-176.

Jaskiewicz, P., J.H. Block, D. Miller, and J.G. Combs. 2014. "Founder versus family owners' impact on pay dispersion among non-CEO top managers implications for firm performance." Journal of Management 43(5): 1524-1552.

Jaskiewicz, P., J.G. Combs, and S.B. Rau. 2015. "Entrepreneurial legacy: Toward a theory of how some family firms nurture transgenerational entrepreneurship." Journal of Business Venturing 30(1): 29-49.

Kellermanns, F.W., K.A. Eddleston, T. Barnett, and A. Pearson (2008). “An exploratory study of family member characteristics and involvement: Effects on entrepreneurial behavior in the family firm." Family Business Review 21(1): 1-14.

Klein, J.I. 1989. "Parenthetic learning in organizations: Toward the unlearning of the unlearning model." Journal of Management Studies 26(3): 291-308.

Kolb, A. 1984. Experiential Learning: Experience as the Source of Learning and Development. Englewood Cliffs, NJ: Prentice-Hall.

Konopaski, M., S.L. Jack, and E. Hamilton. 2015. "How family business members learn about continuity." Academy of Management Learning \& Education 14(3): 347-364.

Kuratko, D.F., R.V. Montagno, and J.S. Hornsby. 1990. "Developing an intrapreneurial assessment instrument for an effective corporate entrepreneurial environment." Strategic Management Journal 11(Summer): 49-58.

Leal-Rodríguez, A.L., S. Eldridge, J.L. Roldán, A.G. Leal-Millán, and J. Ortega-Gutiérrez. 2015. "Organizational unlearning, innovation outcomes, and performance: The moderating effect of firm size." Journal of Business Research 68(4): 803-809.

Lechner, C., and M. Dowling. 2003. "Firm networks: External relationships as sources for the growth and competitiveness of entrepreneurial firms." Entrepreneurship \& Regional Development 15(1): 1-26.

Li, Y., H. Chen Y. Liu, and M.W. Peng. 2014. "Managerial ties, organizational learning, and opportunity capture: A social capital perspective." Asia Pacific Journal of Management 31(1): 271-291.

Lincoln, Y.S., and E.G. Guba. 1985. Naturalistic inquiry. Newbury Park, CA: Sage Publications. 
Lumpkin, G.T., K.H. Brigham, and T.W. Moss. 2010. "Long-term orientation: Implications for the entrepreneurial orientation and performance of family businesses." Entrepreneurship \& Regional Development 22(3-4): 241-264.

Marchisio, G., P. Mazzola, S. Sciascia, M. Miles, and J. Astrachan. 2010. "Corporate venturing in family business: The effects on the family and its members." Entrepreneurship \& Regional Development 22(3-4): 349-377.

McAdam, M., E. Clinton, M. Brophy, and J.R. Gamble. 2018. "A Multilevel Perspective of Organizational Learning in the Transgenerational Entrepreneurial Family Firm." Paper presented at the European Academy of Management Conference, Reykjavik, Iceland, June 19-22.

McAdam, R., R. Reid, and N. Mitchell. 2010. "Longitudinal development of innovation implementation in family-based SMEs: The effects of critical incidents." International Journal of Entrepreneurial Behavior Research 16(5): 437-456.

McCann, J.E. III, A.Y. Leon-Guerrero, and J.D. Jr. Haley. 2001. "Strategic goals and practices of innovative family businesses." Journal of Small Business Management 39(1): 50-59.

Miles, M.B., and A.M. Huberman. 1994. Qualitative data analysis: An expanded sourcebook. Beverly Hills, CA: Sage Publications.

Miller, D., and I. Le Breton-Miller. 2005. Managing for the long run: Lessons in competitive advantage from great family businesses. Boston: Harvard Business Press.

Minniti, M., and W. Bygrave. 2001. "A dynamic model of entrepreneurial learning." Entrepreneurship Theory \& Practice 25(3): 5-16.

Mwasalwiba, E., H. Dahles, and I. Wakkee. 2012. "Graduate entrepreneurship in Tanzania: Contextual enablers and hindrances." European Journal of Scientific Research 76(3): 386-402.

Nordqvist, M., and L. Melin. 2010. "Entrepreneurial families and family firms." Entrepreneurship \& Regional Development 22(3-4): 211-239.

OECD. 2017. “Global Interim Economic Outlook, March 2017.” OECD. Accessed March 14 2017. http://www.oecd.org/eco/outlook/economic-outlook/.

Palinkas, L.A., S.M. Horwitz, C.A. Green, J.P. Wisdom, N. Duan, and K. Hoagwood. 2015. "Purposeful sampling for qualitative data collection and analysis in mixed method implementation research." Administration and Policy in Mental Health and Mental Health Services Research 42(5): 533-544.

Pittaway, L., and J. Cope. 2007. "Simulating entrepreneurial learning: Integrating experiential and collaborative approaches to learning." Management Learning 38(2): 211-233.

Politis, D. 2005. "The process of entrepreneurial learning: A conceptual framework." Entrepreneurship Theory \& Practice 29(4): 399-424.

Poza, E.J. 2010. "Late stage entrepreneurial activity: What students should know about family -owned and family-controlled companies." In Entrepreneurship and Family Business, edited by J. Katz and A.C. Corbett, 359-366. Bingley, UK: Emerald Group Publishing Limited.

Pratt, M. G. 2008. "Fitting oval pegs into round holes: Tensions in evaluating and publishing qualitative research in top-tier North American journals." Organizational Research Methods 11(3): 481-509.

Randerson, K., C. Bettinelli, A. Fayolle, and A. Anderson. 2015. "Family entrepreneurship as a field of research: Exploring its contours and contents." Journal of Family Business Strategy 6(3): 143-154.

Randerson, K., G. Dossena, and A. Fayolle. 2016. "The futures of family business: Family entrepreneurship." Futures 75: 36-43. 
Randerson, K., H. Frank, C. Dibrell, and E. Memili. 2017. Special issue: "From Family to Families: Pushing family entrepreneurship forward" Call for papers. Entrepreneurship \& Regional Development.

Randolph, R.V., Z. Li, and J.J. Daspit. 2017. "Toward a typology of family firm corporate entrepreneurship." Journal of Small Business Management 55(4): 530-546.

Rebernik, M., and K. Širec. 2007. "Fostering innovation by unlearning tacit knowledge." Kybernetes 36(3/4): 406-419.

Rogoff, E.G., and R.K.Z. Heck. 2003. "Evolving research in entrepreneurship and family business: Recognizing family as the oxygen that feeds the fire of entrepreneurship." Journal of Business Venturing 18(5): 559-566.

Salvato, C., and G. Corbetta. 2013. "Transitional leadership of advisors as a facilitator of successors' leadership construction." Family Business Review 26(3): 235-255.

Sarasvathy, S., K. Kumar, J.G. York and S. Bhagavatula 2014. An effectual approach to international entrepreneurship: Overlaps, challenges, and provocative possibilities. Entrepreneurship Theory \& Practice, 38(1): 71-93.

Schuman, A., S. Stutz, and J. Ward. 2010. Family business as paradox. Basingstoke, UK: Palgrave Macmillan.

Sieger, P., T. Zellweger, R.S. Nason, and E. Clinton. 2011. "Portfolio entrepreneurship in family firms: a resource-based perspective." Strategic Entrepreneurship Journal 5(4): 327-351.

Sole, D., and D.G. Wilson. 2002. "Storytelling in organizations: The power and traps of using stories to share knowledge in organizations." LILA, Harvard Graduate School of Education. 1-12.

Stigliari, I., and D. Ravasi. 2016. "Combining qualitative methods to study collective cognition in organizations." In Handbook of qualitative organizational research: Innovative pathways and methods, edited by Elsbach, K.D., and R.M. Kramer, 444-453. USA: Routledge.

Taylor, D.W, and R. Thorpe. 2004. "Entrepreneurial learning: a process of coparticipation." Journal of Small Business and Enterprise Development 11(2): 203-211.

Tsang, E., and S. Zahra. 2008. "Organizational unlearning." Human Relations 61(10): 14351462.

Yamada, J. 2004. "A multi-dimensional view of entrepreneurship: Towards a research agenda on organisation emergence." Journal of Management Development 23(4): 289-320.

Volberda, H., C. Baden-Fuller, and F. Van Den Bosch. 2001. "Mastering strategic renewal: Mobilising renewal journeys in multi-unit firms." Long Range Planning 34(2): 159178.

Waddill, D., and M. Marquardt. 2011. "Adult learning theories and the practice of action learning." In Action Learning in Practice, edited by Peddler, M., 415-427. Farnham, UK: Gower Publishing.

Wang, C.L., and H. Chugh. 2014. "Entrepreneurial learning: past research and future challenges." International Journal of Management Reviews 16(1): 24-61.

Yin, R.K. 2009. Case study research: design and methods. Essential guide to qualitative methods in organizational research. Thousand Oaks, CA: Sage.

Yin, R.K. 2016. Qualitative research from start to finish. New York: The Guilford Press.

Zahra, S.A. 2012. "Organizational learning and entrepreneurship in family firms: Exploring the moderating effect of ownership and cohesion." Small Business Economics 38(1): 51-65.

Zellweger, T. 2007. "Time horizon, costs of equity capital, and generic investment strategies of firms." Family Business Review 20(1): 1-15. 
Zellweger, T.M., F.W. Kellermanns, J.J. Chrisman, and J.H. Chua. 2012. "Family control and family firm valuation by family CEOs: The importance of intentions for transgenerational control." Organization Science 23(3): 851-868.

Zellweger, T.M., R.S. Nason, M. Nordqvist, and C.G. Brush. 2013. "Why do family firms strive for nonfinancial goals? An organizational identity perspective." Entrepreneurship Theory \& Practice 37(2): 229-248.

Zhong, E., W. Fan, J. Wang, L. Xiao, and Y. Li .2012. "Comsoc: Adaptive transfer of user behaviors over composite social network." In Proceedings of the 18th ACM SIGKDD international conference on Knowledge discovery and data mining, 696-704, Beijing, China, Aug 12. 
Table 1. Overview of Cases

\begin{tabular}{|c|c|c|c|c|}
\hline Case & TEF A & TEF B & TEF C & TEF D \\
\hline Industry & $\begin{array}{l}\text { Timber processing; } \\
\text { sawmilling }\end{array}$ & $\begin{array}{l}\text { Food (oat-based branded } \\
\text { cereals) }\end{array}$ & Wastewater treatment & $\begin{array}{l}\text { Farm machinery } \\
\text { manufacturer and supplier }\end{array}$ \\
\hline Year founded & 1913 & 1785 & 1968 & 1963 \\
\hline Age / Generation & 104 / Third & 232 / Seventh & 49 / Second & 54 / Second \\
\hline Employees / Turnover ${ }^{3}$ & $380 / € 127$ million & 55 / €20 million & 300 / €72 million & $50 / € 10$ million \\
\hline Family MD / Chairman & Yes (Co-MDs) & Yes & Yes & Yes \\
\hline Family ownership & $100 \%$ & $100 \%$ & $100 \%$ & $100 \%$ \\
\hline No. of TEF members & 5 & 6 & 12 & 5 \\
\hline No. of living generations & 1 & 2 & 2 & 2 \\
\hline $\begin{array}{l}\text { Geographical dispersion } \\
\text { of TEF members } 4\end{array}$ & $4 / 1$ & $5 / 1$ & $9 / 3$ & $5 / 0$ \\
\hline Frequency of meetings 5 & FC: 4 / BM: 4 & FC: 4 / BM: 4 & FC: 6 / BM: 4 & FC: 4 / BM: 4 \\
\hline $\begin{array}{l}\text { Most recent ownership } \\
\text { transition type }\end{array}$ & Recycled & Devolutionary & Evolutionary & Evolutionary \\
\hline Familial Relationships & $\begin{array}{l}\text { Brothers }(G 3) \\
\text { Managing Director*+ } \\
\text { Managing Director*+ } \\
\text { Board Member*+ }\end{array}$ & $\begin{array}{l}\text { Parents }(G 6) \\
\text { Managing Director*+ } \\
\text { Non-Exec Director } \\
\text { Children }(G 7) \\
\text { Int. Business Dvlpt. Manager*+ } \\
\text { Financial Controller*+ } \\
\text { Brand Manager }+\end{array}$ & $\begin{array}{l}\text { Brothers }(G 1) \\
\text { Managing Director*+ } \\
\text { Board Director* } \\
\text { Board Director*+ } \\
\text { Cousins }(G 2) \\
\text { Deputy MD*+ } \\
\text { Commercial Director* }\end{array}$ & $\begin{array}{l}\text { Parent }(G 1) \\
\text { Executive Chairman* } \\
\text { Children }(G 2) \\
\text { General Manager* } \\
\text { Business Dvlpt. Manager* } \\
\text { Sales \& Marketing Director* } \\
\text { Manager* }\end{array}$ \\
\hline
\end{tabular}

\footnotetext{
${ }^{3}$ Sourced through the national companies register, as accessed through the FAME database of Bureau van Dijk.

${ }^{4}$ National/international

${ }^{5}$ Family Council (FC) / Board Meetings (BM) per annum.
} 
Table 2. Archival Sources*

\begin{tabular}{|c|c|c|c|c|}
\hline Year & TEF A & TEF B & TEF C & TEF D \\
\hline Pre-1920 & MA (4), GD (2) & MA (2), GD (3) & & \\
\hline 1921-1930 & MA (3), GD (2) & GD (3) & & \\
\hline 1931-1940 & MA (1) & GD (1) & & \\
\hline $1941-1950$ & CR (1), GD (4) & GD (2) & & \\
\hline $1951-1960$ & CR (1), MA (3) & MA (1) & & \\
\hline 1961-1970 & $\begin{array}{l}\text { CR (1), VTR (1), GD (2), } \\
\text { MA (1), OF (1) }\end{array}$ & $\mathrm{CR}(1), \mathrm{OF}(1), \mathrm{GD}(1)$ & MA (2), GD (3) & \\
\hline 1971-1980 & $\begin{array}{l}\text { CR (1), VTR (1), MA (6), } \\
\text { OF (1) }\end{array}$ & CR (2), VTR (1), OF (1) & OF (1), GD (3), MA (2) & \\
\hline 1981-1990 & $\begin{array}{l}\text { CR (1), MA (18), GD (1), } \\
\text { OF (1) }\end{array}$ & $\begin{array}{l}\text { CR (2), MA (2), VTR (1), } \\
\text { OF (1) }\end{array}$ & $\begin{array}{l}\text { OF (1), MA (2), CR (2), } \\
\text { VTR (2) }\end{array}$ & MA (3) \\
\hline 1991-2000 & $\begin{array}{l}\text { CR (1), VTR (2), MA } \\
\text { (15), OF (1) }\end{array}$ & $\begin{array}{l}\text { CR (1), VTR (3), OF (1), } \\
\text { GD (1), CP (1) }\end{array}$ & $\begin{array}{l}\text { OF (1), MA (6), CR (4), } \\
\text { CP (1), VTR (1), GD (1) }\end{array}$ & MA (6) \\
\hline 2001-2010 & $\begin{array}{l}\text { CR (1), MA (14), CP (2), } \\
\text { GD (2), OF (1) }\end{array}$ & $\begin{array}{l}\text { CR (2), VTR (8), OF (1), } \\
\text { GD (1), CP (1) }\end{array}$ & $\begin{array}{l}\text { OF (1), MA (9), CR (10), } \\
\text { CP (2) }\end{array}$ & MA (4), VTR (2), PR (15) \\
\hline 2011-2016 & $\begin{array}{l}\text { CR (1), VTR (3), MA } \\
\text { (30), CP (3), GD (2), OF } \\
\text { (1) }\end{array}$ & $\begin{array}{l}\text { CR (2), MA (2), VTR (8), } \\
\text { OF (1), CP (4) }\end{array}$ & $\begin{array}{l}\text { OF (1), MA (14), CR (20), } \\
\text { CP (6), VTR (5), GD (2) }\end{array}$ & MA (5), PR (10) \\
\hline Total & 136 & 62 & 102 & 45 \\
\hline
\end{tabular}

* $\mathrm{MA}=$ media articles, $\mathrm{CR}=$ Corporate reports, $\mathrm{VTR}=$ video, television, radio, $\mathrm{CP}=$ corporate presentations, $\mathrm{GD}=$ government document, $\mathrm{OF}=$ official filings (companies register), $\mathrm{PR}=$ press release. 


\section{Table 3. Interview and Observation Data}

\begin{tabular}{|c|c|c|c|c|c|c|c|c|c|}
\hline \multicolumn{2}{|l|}{ Interviews* } & \multicolumn{2}{|c|}{ TEF A } & \multicolumn{2}{|c|}{ TEF B } & \multicolumn{2}{|c|}{ TEF C } & \multicolumn{2}{|c|}{ TEF D } \\
\hline \multirow{2}{*}{\multicolumn{2}{|c|}{ Chairman }} & A & $\mathbf{B}$ & $\mathbf{A}$ & B & $\mathbf{A}$ & B & $\mathbf{A}$ & $\mathbf{B}$ \\
\hline & & - & - & - & - & - & - & 1 & $1 \mathrm{G}$ \\
\hline \multicolumn{2}{|l|}{ Board Member (BM) } & 1 & $3 G$ & - & - & 2 & $1 \mathrm{G} ; 1 \mathrm{G}$ & - & - \\
\hline \multicolumn{2}{|l|}{ Family advisor } & - & - & - & - & - & - & 2 & Non \\
\hline \multicolumn{2}{|l|}{ Financial Controller (FC) } & 1 & Non & 1 & $7 \mathrm{G}$ & - & - & - & - \\
\hline \multicolumn{2}{|l|}{ General Manager (GM) } & - & - & - & - & - & - & 1 & $2 \mathrm{G}$ \\
\hline \multicolumn{2}{|l|}{ Managing Director (MD) } & 2 & $3 \mathrm{G} ; 3 \mathrm{G}$ & 1 & $6 \mathrm{G}$ & 1 & $1 \mathrm{G}$ & - & - \\
\hline \multicolumn{2}{|l|}{ Other Director } & - & - & - & - & 2 & $2 \mathrm{G} ; 2 \mathrm{G}$ & - & - \\
\hline \multicolumn{2}{|l|}{ Other Manager } & 2 & Non & 2 & Non; $7 \mathrm{G}$ & 2 & Non & 1 & $2 \mathrm{G}$ \\
\hline \multicolumn{2}{|c|}{ Sales/Marketing Director } & 1 & Non & 1 & Non & - & - & 1 & $2 \mathrm{G}$ \\
\hline \multirow{2}{*}{\multicolumn{2}{|c|}{$\begin{array}{l}\text { Business Development Officer } \\
\text { (BDO) } \\
\text { Other }\end{array}$}} & - & - & - & - & - & - & 1 & $2 \mathrm{G}$ \\
\hline & & - & - & - & - & 1 & Non & 5 & Non \\
\hline & 7 & 3 & 5 & 3 & 8 & 5 & 12 & 5 \\
\hline \multicolumn{2}{|l|}{$\begin{array}{l}\text { I otal } \\
\text { Observations }\end{array}$} & \multicolumn{2}{|c|}{ TEF A } & \multicolumn{2}{|c|}{ TEF B } & \multicolumn{2}{|c|}{ TEF C } & \multicolumn{2}{|c|}{ TEF D } \\
\hline \multirow{4}{*}{\multicolumn{2}{|c|}{$\begin{array}{l}\text { Plant tours } \\
\text { Family dinner } \\
\text { Corporate presentations } \\
\text { Family council meetings }\end{array}$}} & \multicolumn{2}{|c|}{3} & \multicolumn{2}{|c|}{3} & \multicolumn{2}{|c|}{2} & \multicolumn{2}{|c|}{2} \\
\hline & & \multicolumn{2}{|c|}{2} & \multicolumn{2}{|c|}{-} & \multicolumn{2}{|c|}{-} & \multicolumn{2}{|c|}{3} \\
\hline & & \multicolumn{2}{|c|}{4} & \multicolumn{2}{|c|}{2} & \multicolumn{2}{|c|}{3} & \multicolumn{2}{|c|}{1} \\
\hline & & & & & & & & & \\
\hline Total & & & & & & & & & \\
\hline
\end{tabular}

* Column A signals no. of interviewees/interviews. Column B signals no. of family members and their generation. 'Non' denotes non-family members (Adapted from Marchisio et al. 2010). 
Table 4. TEF A Data Analysis

\begin{tabular}{|c|c|c|c|c|c|c|c|c|c|}
\hline \multicolumn{4}{|c|}{ Identify Critical Incidents } & \multirow[t]{2}{*}{ Gen/s } & \multirow[t]{2}{*}{ Learning Outcomes } & \multirow{2}{*}{$\begin{array}{c}\text { Entrepreneurial } \\
\text { Behaviour Enablers }\end{array}$} & \multicolumn{3}{|c|}{ Entrepreneurial Behaviours } \\
\hline Year & Critical Incidents & Evidence & Ext./Int. & & & & Behaviour & Value & Perpetuation \\
\hline 1968 & $\begin{array}{l}\text { Hurricane hits neighbouring } \\
\text { country and creates extensive } \\
\text { damage to forests. }\end{array}$ & $\mathrm{aC}$ & Ext. & G2 & $\begin{array}{l}\text {-Secure materials } \\
\text { internationally. } \\
\text {-Establish long-term } \\
\text { supply. }\end{array}$ & $\begin{array}{l}\text { Predecessor legacy } \\
\text { building. }\end{array}$ & $\begin{array}{l}\text { Opportunity } \\
\text { recognition and } \\
\text { risk-taking. }\end{array}$ & $\begin{array}{l}\text { Ent. + } \\
\text { Eco. }\end{array}$ & G3 \\
\hline 2004 & $\begin{array}{l}\text { Serious fire destroys home } \\
\text { plant. }\end{array}$ & $\mathrm{AC}$ & Ext. & G3 & $\begin{array}{l}\text {-Prioritise business } \\
\text { survival over family } \\
\text { needs. } \\
\text {-Manage adversity. } \\
\text {-Witness loyalty of } \\
\text { workforce. }\end{array}$ & $\begin{array}{l}\text { Predecessor legacy } \\
\text { building. }\end{array}$ & $\begin{array}{l}\text { Strategic } \\
\text { regeneration. }\end{array}$ & $\begin{array}{l}\text { Ent. }+ \\
\text { Soc. }\end{array}$ & - \\
\hline
\end{tabular}


Table 5. TEF B Data Analysis

\begin{tabular}{|c|c|c|c|c|c|c|c|c|c|}
\hline \multicolumn{4}{|c|}{ Identify Critical Incidents } & \multirow[t]{2}{*}{ Gen/s } & \multirow[t]{2}{*}{ Learning Outcomes } & \multirow{2}{*}{$\begin{array}{c}\text { Entrepreneurial } \\
\text { Behaviour Enablers }\end{array}$} & \multicolumn{3}{|c|}{ Entrepreneurial Behaviours } \\
\hline Year & Critical Incidents & Evidence & Ext./Int. & & & & Behaviour & Value & Perpetuation \\
\hline 1985 & $\begin{array}{l}\text { Entry to the cold cereals } \\
\text { market. }\end{array}$ & $\mathrm{aC}$ & Ext. & G6 & $\begin{array}{l}\text {-Stick to core area. } \\
\text {-Taking well-measured } \\
\text { risks. }\end{array}$ & $\begin{array}{l}\text { Entrepreneurial } \\
\text { education and } \\
\text { experience. } \\
\text { Entrepreneurial } \\
\text { mentoring. }\end{array}$ & $\begin{array}{l}\text { Diversifying and } \\
\text { risk-taking. }\end{array}$ & $\begin{array}{l}\text { Ent. + } \\
\text { Eco. }\end{array}$ & G7 \\
\hline 1997 & $\begin{array}{l}\text { First non-family } \\
\text { directorship. }\end{array}$ & $\mathrm{AC}$ & Int. & G6 & $\begin{array}{l}\text {-Adopt non-family } \\
\text { expertise. } \\
\text {-Develop marketing } \\
\text { strategy. }\end{array}$ & $\begin{array}{l}\text { Entrepreneurial } \\
\text { mentoring. } \\
\text { Predecessor legacy } \\
\text { building. }\end{array}$ & $\begin{array}{l}\text { Strategic } \\
\text { regeneration. }\end{array}$ & $\begin{array}{l}\text { Ent. + } \\
\text { Eco. }+ \\
\text { Soc. }\end{array}$ & G7 \\
\hline 2000 & $\begin{array}{l}\text { Buyout of shares which } \\
\text { makes Managing } \\
\text { Director full owner. }\end{array}$ & $\mathrm{aC}$ & Int. & G6 & $\begin{array}{l}\text {-Avoid complex ownership } \\
\text { structure. } \\
\text {-Retain family involvement. }\end{array}$ & $\begin{array}{l}\text { Safeguard family } \\
\text { control and influence. } \\
\text { Reduced ownership } \\
\text { complexity. }\end{array}$ & $\begin{array}{l}\text { Opportunity } \\
\text { seeking and risk- } \\
\text { taking. }\end{array}$ & $\begin{array}{l}\text { Ent. + } \\
\text { Eco. }+ \\
\text { Soc. }\end{array}$ & - \\
\hline 2007 & $\begin{array}{l}\text { Seventh generation joins } \\
\text { the firm. }\end{array}$ & $\mathrm{AC}$ & Int. & $\begin{array}{l}\text { G6 } \\
\text { G7 }\end{array}$ & $\begin{array}{l}\text { - Apply best practice gained } \\
\text { from outside experience to } \\
\text { family business. }\end{array}$ & $\begin{array}{l}\text { Entrepreneurial } \\
\text { education and } \\
\text { experience. } \\
\text { Predecessor legacy } \\
\text { building. }\end{array}$ & $\begin{array}{l}\text { Striving for } \\
\text { efficiency. }\end{array}$ & $\begin{array}{l}\text { Ent. }+ \\
\text { Eco. }\end{array}$ & G7 \\
\hline
\end{tabular}


Table 6. TEF C Data Analysis

\begin{tabular}{|c|c|c|c|c|c|c|c|c|c|}
\hline \multicolumn{4}{|c|}{ Identify Critical Incidents } & \multirow[t]{2}{*}{ Gen/s } & \multirow[t]{2}{*}{ Learning Outcomes } & \multirow{2}{*}{$\begin{array}{c}\text { Entrepreneurial } \\
\text { Behaviour Enablers }\end{array}$} & \multicolumn{3}{|c|}{ Entrepreneurial Behaviours } \\
\hline Year & Critical Incidents & Evidence & Ext./Int. & & & & Behaviour & Value & Perpetuation \\
\hline 1973 & $\begin{array}{l}\text { Decision to leave electrical } \\
\text { goods and focus on pumps. }\end{array}$ & $\mathrm{aC}$ & Ext. & G1 & $\begin{array}{l}\text {-Develop a strong core } \\
\text { product offering. } \\
\text {-Geographically expand } \\
\text { operations. } \\
\text {-Be adaptive. }\end{array}$ & $\begin{array}{l}\text { Predecessor legacy } \\
\text { building. }\end{array}$ & Diversifying. & $\begin{array}{l}\text { Ent. + } \\
\text { Soc. }\end{array}$ & G2 \\
\hline 1981 & $\begin{array}{l}\text { Non-family technical director } \\
\text { receives 10\% equity on } \\
\text { appointment. }\end{array}$ & $\mathrm{aC}$ & Ext. & G1 & $\begin{array}{l}\text {-Adopt non-family } \\
\text { expertise. } \\
\text {-Share ownership } \\
\text { privilege with non- } \\
\text { family. }\end{array}$ & $\begin{array}{l}\text { Entrepreneurial } \\
\text { mentoring. }\end{array}$ & $\begin{array}{l}\text { Opportunity seeking } \\
\text { and recognizing. }\end{array}$ & $\begin{array}{l}\text { Ent. }+ \\
\text { Eco. }\end{array}$ & - \\
\hline
\end{tabular}


Table 7. TEF D Data Analysis

\begin{tabular}{|c|c|c|c|c|c|c|c|c|c|}
\hline \multicolumn{4}{|c|}{ Identify Critical Incidents } & \multirow[t]{2}{*}{ Gen/s } & \multirow[t]{2}{*}{ Learning Outcomes } & \multirow{2}{*}{$\begin{array}{c}\text { Entrepreneurial } \\
\text { Behaviour Enablers }\end{array}$} & \multicolumn{3}{|c|}{ Entrepreneurial Behaviours } \\
\hline $\begin{array}{c}\text { Yea } \\
\mathbf{r}\end{array}$ & Critical Incidents & Evidence & Ext./Int. & & & & Behaviour & Value & Perpetuation \\
\hline 2012 & $\begin{array}{l}\text { Executive Chairman } \\
\text { returns and begins } \\
\text { restructuring the } \\
\text { company. }\end{array}$ & $\mathrm{AC}$ & Int. & $\begin{array}{l}\text { G1 } \\
\text { G2 }\end{array}$ & $\begin{array}{l}\text {-Manage adversity. } \\
\text {-Be adaptive. } \\
\text {-Resolve family tensions. }\end{array}$ & $\begin{array}{l}\text { Predecessor legacy } \\
\text { building. }\end{array}$ & $\begin{array}{l}\text { Strategic } \\
\text { regeneration and } \\
\text { striving for } \\
\text { efficiency. }\end{array}$ & $\begin{array}{l}\text { Eco. + } \\
\text { Ent. }\end{array}$ & G2 \\
\hline 2013 & $\begin{array}{l}\text { Family Holdings Group } \\
\text { is created. }\end{array}$ & Ac & Int. & $\begin{array}{l}\text { G1 } \\
\text { G2 }\end{array}$ & $\begin{array}{l}\text {-Grow the family business. } \\
\text {-Spread the risk. } \\
\text {-Create a space for next } \\
\text { generation to build an } \\
\text { entrepreneurial portfolio. }\end{array}$ & $\begin{array}{l}\text { Safeguard family } \\
\text { control and } \\
\text { influence. }\end{array}$ & $\begin{array}{l}\text { Diversifying and } \\
\text { risk-taking. }\end{array}$ & $\begin{array}{l}\text { Eco. + } \\
\text { Ent. }+ \\
\text { Soc. }\end{array}$ & G2 \\
\hline
\end{tabular}


Figure 1. Theoretical model with propositions

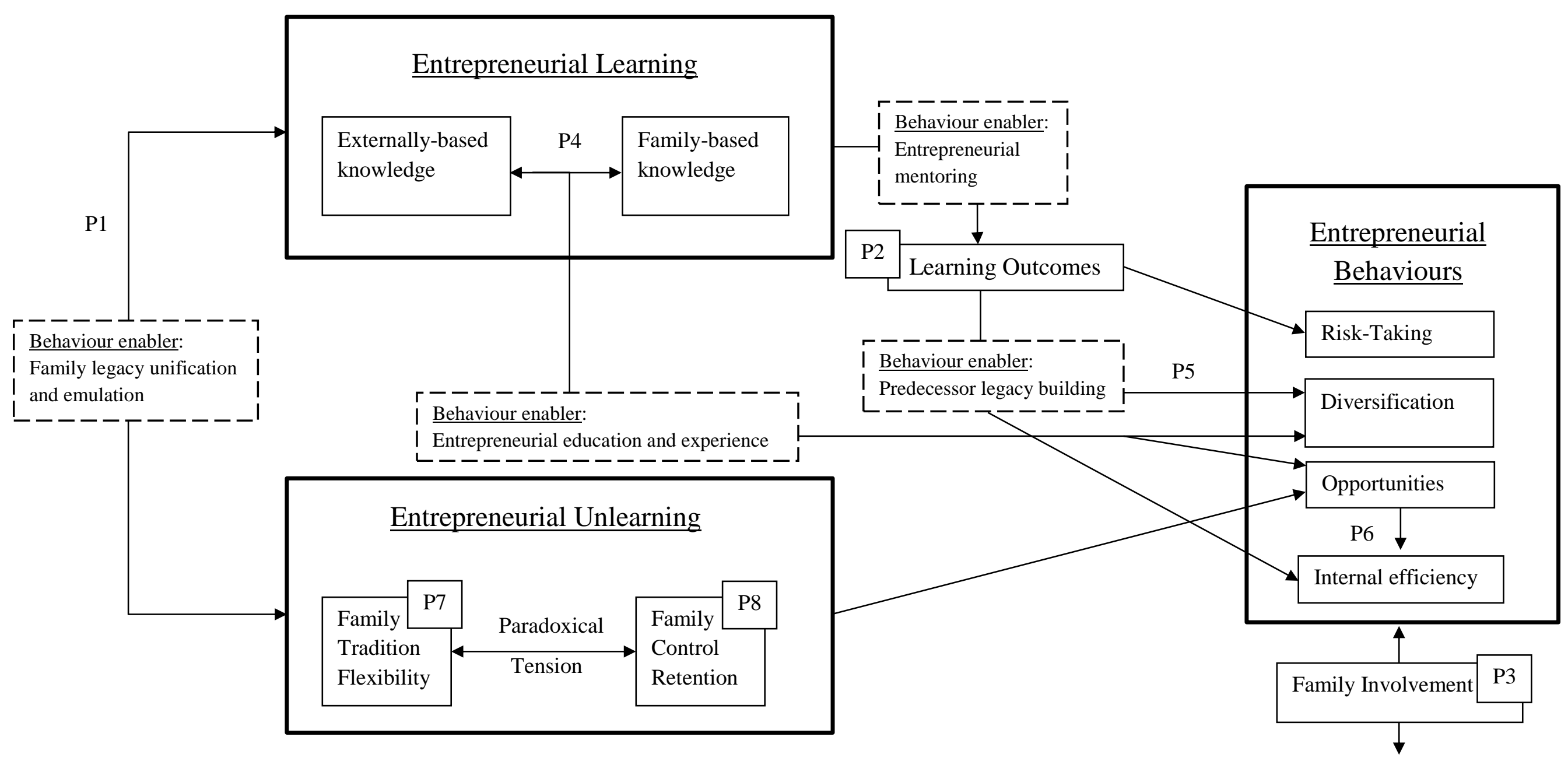


Family/Firm Decision-Making 